\title{
COMPARTIVE EVALUTION OF A NEW ENDODONTIC IRRIGATION SOLUTION -APPLE VINEGAR, GINGER OIL AND SODIUM HYPOCHLORITE TO REMOVE THE SMERA LAYER BY SCANING ELECTRON MICROSCOPE STUDY
}

\author{
Lanja A. Ali, Intesar S. Toma and RaZawa K.SAeEd \\ Dept. of Conservative Dentistry, College of Dentistry, Hawler Medical University, Kurdistan Region- Iraq
}

(Accepted for Publication: August 29, 2019)

\begin{abstract}
Introduction: A three dimensional seal is the one of main steps in the successful root canal treatment .The smear layer that has been created on the dentinal wall during root canal instrumentation should be removed by using irrigation solution . Irrigation solution should be always used with mechanical preparation of root canal system as an important part for successful endodontic treatment

Aim: The aim of this in vitro study was to compare the efficacy of four irrigating solutions in removing the smear layer.

Materials and Methods: A total of 40 single rooted teeth were selected and instrumented and then assigned in a random manner into 4 groups of 10 each. Each group treated with different solutions (Normal saline, Sodium hypochlorite, Apple vinegar and Ginger oil). Scanning Electron Microscope had been used to measure the effect of these materials (solutions) in removal of smear layer from three root sections (Apical, middle and coronal third of the root).

Conclusion: According to the Torbinjad criteria; Apple vinegar showed the best result in smear layer removal for the whole root length and no single irrigant can accomplish all the tasks required by irrigation.
\end{abstract}

KEYWORDS: Smear layer,Apple vinegar, Ginger oil,Irrigation

\section{INTRODUCTION}

" $\bar{C}^{\mathrm{n}}$ ndodontics" has stepped into the arena where more and more people are now realizing that saving even an isolated natural tooth is worth the time and effort as there is no substitute for a healthy natural dentition in order to maintain the integrity of the arch, function and esthetics of the masticatory apparatus.

The key objectives of endodontic therapy are cleaning and shaping, obturation of the root canal system in three dimensions and preventing reinfection. Cleaning and shaping are considered to be the most important and most demanding aspect. There is an old age saying in endodontics that is relevant even today "what is taken out of the root canal may be more important than what is put into the root canal."(1)

Irrigation solutions that used for irrigation of root canal have proved to be very important in root canal treatment, as they help in lubrication, disinfection, debris removal, and dissolving both organic and inorganic tissue from the root canal system $^{(2)}$

So that, irrigation procedure is considered as an important step of root canal cleaning and disinfection .because complete debridement and disinfection cannot be achieved only by instrumentation.. In addition to disinfection, irrigants can also help remove the smear layer from the radicular wall. ${ }^{(3)}$

A large number of substances have been used as root canal irrigants, including acids (citric and phosphoric), chelating agents (EDTA), proteolytic enzymes, alkaline solutions (sodium hypochlorite, sodium hydroxide, urea and potassium hydroxide), oxidative agents (hydrogen peroxide and Gly-Oxide) ${ }^{(4)}$. Apple vinegar has been tested by researchers in the field of dentistry as a chelating agent ${ }^{(5)}$, Apple cider vinegar is used in a wide number of health-related issues such as in cancer, cardiovascular diseases, body and joint pains, diabetes, and weight loss. Its antimicrobial action is mainly due to the presence of acetic acid in it, that is, it causes loss of cell integrity. This also can be used in dentistry as a potent root canal 
irrigant. Very few studies have been carried out using apple cider vinegar as a potential root canal irrigant. ${ }^{(6)}$

Accurate debridement of root canals is recommended in most endodontic treatment. ${ }^{(7)}$ Currently, various methods have been introduced to remove the smear layer which includes chemical, ultrasonic, and laser techniques, neither of them has been accepted universally nor they have proved to be more operative. ${ }^{(8)}$

Studies have been conducted with the aim of using chelating agents that would be more efficient and biocompatible with the organic structures than EDTA. Therefore, citric acid (9) and apple vinegar ${ }^{(10)}$ have been studied. Apple vinegar has proven antimicrobial action, reduces dentinal microhardness, in addition to removing the smear layer. ${ }^{(11)}$

\section{MATERIALS AND METHODS}

Recently fourty extracted non-carious human mandibular and maxillary single rooted teeth obtained from patients 13- 60 years old were stored in saline at room temperature. The criteria for selection were length, straightness, and the apical morphology. If the apex was open to over \# $20 \mathrm{~K}$-file in diameter, the tooth was rejected and not used in the study. Teeth with average root length of 14-16 mm were selected. A total of 40 teeth were selected and assigned in a random manner into 4 groups of 10 each. ${ }^{(12)}$

The root surfaces of teeth were debrided and placed in 3\% sodium hypochlorite solution for $24 \mathrm{hrs}$ to remove any remaining organic tissue. The teeth were stored in normal saline till the beginning of the study. After preparing conventional access cavity, the working length of all the teeth was established by passing a no. 10 file to the apical foramen and then reducing the length by $1 \mathrm{~mm}$. The apical portion of the root tip was covered with sticky wax. ${ }^{(5)}$
Different types of irrigation fluids had been used. Irrigation solution which is normal saline considered as a control group, 30-gauge needle with side vent a blunt distal end was then attached to the syringe for irrigation. $5 \% \mathrm{NaOCl}$ and normal saline were used.

The irrigations that are used in this study are (Normal saline (as control), 5\% sodium hypochlorite, $95 \%$ apple vinegar, and $100 \%$ ginger oil).

$-5 \%$ of sodium hypochlorite prepared by mixing of $95 \mathrm{ml}$ of normal saline with $5 \mathrm{ml}$ of sodium hypochlorite at home. ${ }^{(12)}$

$-95 \%$ apple vinegar contains $5 \%$ sodium metabisulfied and 95\% apple vinegar.

\section{Preparation of the root canal:}

The biomechanical preparation was done by using protaper (X Smart) densply rotary instruments in hand piece speed 300 torque 3.0 gear 16:1 up to the apical size F2 was used by crown down technique following the manufacturer instruction. SX used with brushing motion for orifice widening and coronal shaping, after that we used shaping file S1 with brushing action for preparing $2 / 3$ of the length of the canal and then repeating using $\mathrm{S} 1$ for the whole length of the root. While S2 used for shaping the full working length of the root. Preparing was finished with finishing files F1, F2 for the full working length of the canal.

The canals were irrigated with $1 \mathrm{ml}$ of either sterile saline solution or sodium hypochlorite $(5 \%)$ after use of each instrument, according to the groups.

A volume of $10 \mathrm{ml}$ volume of irrigant was used $5 \mathrm{ml}$ as initial irrigation during root canal preparation, and $5 \mathrm{ml}$ of test solution as a final solution for removal of smear layer. The irrigant was delivered with a 30 -gauge, $1 \frac{1}{2}$ inch needle (ProRinse, Densply). The specimens were then divided into four groups, depending upon irrigant/irrigants used as a final rinses as shown in Table

Table (1): Study Group

\begin{tabular}{lll}
$\begin{array}{l}\text { Group } \\
(n=40)\end{array}$ & $\begin{array}{l}\text { Irrigating solution during root canal } \\
\text { preparation }(5 \mathrm{ml})\end{array}$ & $\begin{array}{l}\text { Final solution for removal of the smear } \\
\text { layer }(5 \mathrm{ml})\end{array}$ \\
\hline A & Saline & Saline \\
B & $5 \% \mathrm{Naocl}$ & $5 \%$ Naocl \\
C & $5 \% \mathrm{Naocl}$ & Apple vinegar \\
D & $5 \% \mathrm{Naocl}$ & Ginger oil
\end{tabular}


After completion of canal preparation till apical size F2, the crowns of all the teeth were removed at the Cemento-enamel junction with separating disks with coolant.

Final rinsing of root canals was done with the test solutions in the following manner:

With the help of 30-gauge Pro Rinse probe, 1 $\mathrm{ml}$ of the test solution was delivered in the canal as near as possible to the apex without binding. Test solution was left in the canal for $5 \mathrm{~min}$ with in-between agitation by \# $15 \mathrm{~K}$-file, followed by remaining $4 \mathrm{ml}$ irrigation. Final irrigation of root canals was done with $3 \mathrm{ml}$ of distilled water to remove any precipitate that might have formed from the test irrigants and the canals were dried with paper points.

\section{Scanning Electron Microscope Analysis:}

Horizontal grooves were made on both buccal and lingual surfaces of the root using a diamond disk without penetration of the canal. With the help of a chisel, the roots were then separated into two halves. The half portion of each root was coded and chosen, containing the most visible part of the apex and the whole canal length. ${ }^{(13)}$ Figure1. One half of the root was discarded and the other half was placed in $2 \%$ glutaraldehyde solution for 24hrs.

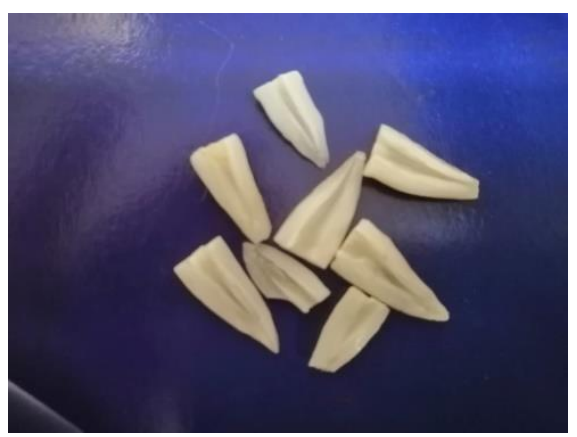

Fig(1): Half of the root

The root surface was divided into three parts (apical, middle, coronal) by using fixed marker. The samples then sent for scanning electron microscope examination and taking photomicrograph for these three parts. The coded and mounted samples were placed in the vacuum chamber of the SEM. The acceleration voltage was standardized to 7 and $20.0 \mathrm{~K}$.V with an emission current of $15.0 \mu \mathrm{A}$ and width of $20 \mathrm{~mm}$. The angle of tilt and the aperture was adjusted to optimize the quality of photomicrograph.

Each sample was micro-graphed at these three areas (apical, middle, coronal) at different magnification and viewed under a SEM. The photomicrographs taken were qualitatively evaluated blindly by three evaluatores, and rated for the degree of cleanliness (Figure2) with regard to the presence of debris, smear layer and patency of dentinal tubules ${ }^{(14)}$ on a scale of 1 to 3 where: $1=$ No smear layer. Clean and open tubules, the surface of the root canals free of the smear layer. $2=$ Moderate smear layer. The surface of the root canals free of the smear layer, but debris found in tubules.

$3=$ Heavy smear layer. The root canal surface and the tubules covered by the smear layer.

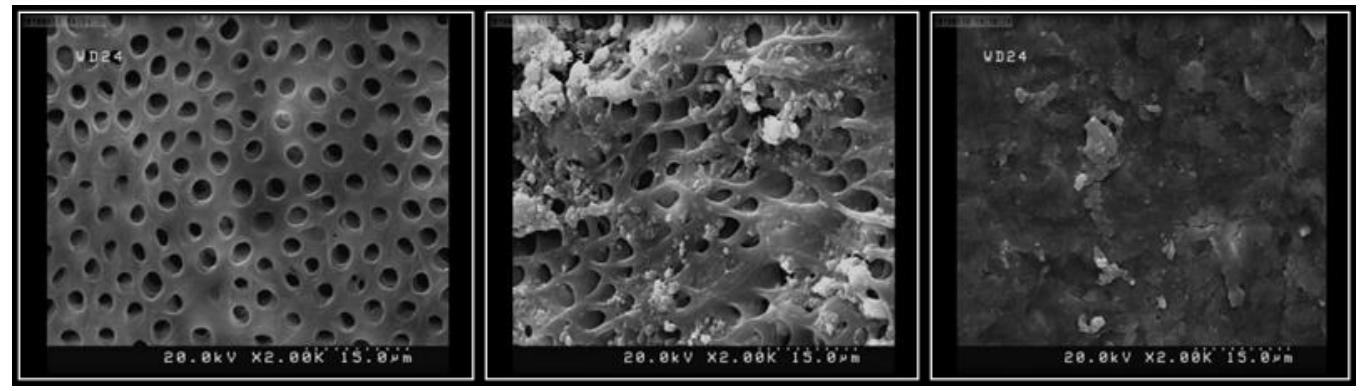


Score1

\section{- Statistical analysis:}

Data were analyzed using the Statistical Package for Social Sciences (SPSS, version 22). Kruskal Wallice test was used to compare the mean rank of the smear layer removal of the study groups. A $p$ value of $\leq 0.05$ was considered statistically significant.

\section{RESULT}

According to the parameters of smear layer removal by type of materials (solutions) and root sections. Apple vinegar showed the least mean

\section{Score 2}

Fig. (2): SEM scores

value for the three root sections (Apical, Middle and Coronal) (1.40, 1.00, and 1.40 respectively). Followed by Sodium hypochlorite with low mean values for both middle and coronal third of the roots (2.00). While Normal saline and Ginger oil showed the highest mean values with (at) different sections. The mean value of the apical and middle third of the roots were (was) (3.00) for normal saline. While Ginger oil showed the mean value of (3.00) for both middle and coronal third.

According to the Torbinjad criteria Apple vinegar showed the best result in smear layer removal for the whole root length.

Table (2): Parameters of smear layer removal by type of material and section.

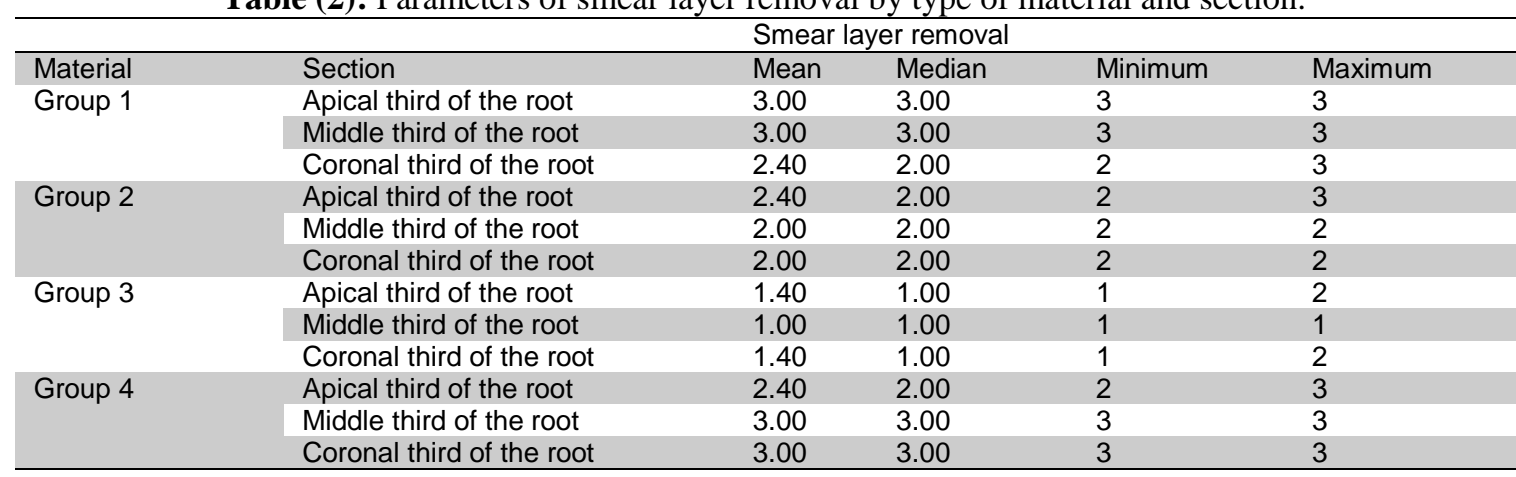

From Table 3 it is obvious that significant differences were detected between the four groups regarding the mean rank of smear layer removal by type of material for each root section at a $(\mathrm{P}<$ $0.001)$. Least mean ranks were detected with
Apple vinegar for the three sections (Apical, Middle, and Coronal) (7.90, 5.50, and 8.70) respectively. While the highest value (33.50) were was detected with ginger oil at the coronal third of the root.

Table (3) :( Kruskal Wallice test) Smear layer removal by type of material, in each of the root sections.

\begin{tabular}{|c|c|c|c|c|c|c|c|}
\hline & & Mean rank & smear la & oval & & & \\
\hline Material & $\mathrm{N}$ & $\begin{array}{l}\text { Apical } \\
\text { third only }\end{array}$ & & $\begin{array}{l}\text { Middle third } \\
\text { only }\end{array}$ & & $\begin{array}{l}\text { Coronal } \\
\text { third only }\end{array}$ & \\
\hline NS & 10 & 31.50 & & 30.50 & & 23.30 & \\
\hline Sodium $\mathrm{h}$. & 10 & 21.30 & $<0.001$ & 15.50 & $<0.001$ & 16.50 & $<0.001$ \\
\hline Apple V. & 10 & 7.90 & & 5.50 & & 8.70 & \\
\hline Ginger oil & 10 & 21.30 & & 30.50 & & 33.50 & \\
\hline
\end{tabular}

For all used solutions except Apple vinegar, the statistical analysis showed significant difference in the mean rank of smear layer removal at $P$ value $<0.05$ (Table 4).

Considering the Normal saline, the table show significant differences in the mean rank of smear layer removal by section of the tooth $\mathrm{P}$ value
(0.001). It's evident that least mean value (9.50) was detected on the coronal third of the root. Also its evident there is no difference between apical and middle third of the root that equal to (18.50) (table 4).

Sodium hypochlorite and Ginger oil also showed a significant differences at a $\mathrm{P}$ value 
$(0.012,0.001)$ respectively. It's evident no difference between the coronal and middle third of the root for each material with a mean rank value $(13.50,18.50)$ respectively. While in the apical third of the root, sodium hypochlorite showed the higher mean value (19.50) but Ginger oil showed the lowest mean value (9.50).
While Apple vinegar was the only material that showed non-significant differences by section of the tooth with $\mathrm{P}$ value (0.072), with the least mean value (11.5) at the middle third and higher mean value at both apical and coronal third of the root with mean value (17.50).

Table (4): :( Kruskal Wallice test) Mean ranks of smear layer removal by section of the tooth, in each type of the

\begin{tabular}{|c|c|c|c|c|}
\hline Material & Section & $\mathbf{N}$ & Mean Rank & $\mathbf{P}$ \\
\hline \multirow[t]{3}{*}{ NS } & Apical third of the root & 10 & 18.50 & \\
\hline & Middle third of the root & 10 & 18.50 & 0.001 \\
\hline & Coronal third of the root & 10 & 9.50 & \\
\hline \multirow[t]{3}{*}{ Sodium } & Apical third of the root & 10 & 19.50 & \\
\hline & Middle third of the root & 10 & 13.50 & 0.012 \\
\hline & Coronal third of the root & 10 & 13.50 & \\
\hline \multirow[t]{3}{*}{ Apple } & Apical third of the root & 10 & 17.50 & \\
\hline & Middle third of the root & 10 & 11.50 & 0.072 \\
\hline & Coronal third of the root & 10 & 17.50 & \\
\hline \multirow[t]{3}{*}{ Genjour oil } & Apical third of the root & 10 & 9.50 & \\
\hline & Middle third of the root & 10 & 18.50 & 0.001 \\
\hline & Coronal third of the root & 10 & 18.50 & \\
\hline
\end{tabular}

\section{DISCUSSION}

Using irrigation solutions in root canal therapy is an essential procedure for the removal of the smear layer. The clinical use of new irrigation and chelating solutions must be preceded by laboratory studies that investigate the benefits and consequences to the human beings. ${ }^{(5)}$ Removing the smear layer enhances disinfection into dentinal tubules in addition to allowing tridimensional sealing of the root canal system..$^{(9)}$ Irrigation with a tissue dissolving antimicrobial solution is a prerequisite for effective removal of the smear layer and remnant pulp debris which may in turn affect sealing ability of filling materials. ${ }^{(15)}$

This is because Apple vinegar is constituted of acetic acid (its main component), malic, lactic, formic, and citric acids. Malic acid is the constituent responsible for the therapeutic property of the solution. ${ }^{(9)}$ The presence of malic acid gives the biocompatibility action to apple cider. In this process, the ethyl alcohol produced is converted and oxidized into acetic acid under the presence of specific microorganisms. This procedure is called acetification. ${ }^{(16)}$ The total amount of calcium ion found in the apple vinegar solution is due to the action of $\mathrm{H}+$ ions present. The more the concentration of $\mathrm{H}+$ ions the more efficient the attack of the acid would be.(13)
Furthermore, the apple cider vinegar has a medicinal potential due to its rich mineral content such as potassium, phosphorus, and magnesium. Despite fully knowing its mechanism of action, it is believed that adsorption, ionic exchange and chelation are responsible for the elimination of dentin calcium ions. ${ }^{(11)}$ Apple vinegar has proven antimicrobial action, reduces dentinal microhardness, ${ }^{(10)}$ in addition to removing the smear layer. ${ }^{(17),(18)}$ Apple vinegar associates a good capacity to remove smear layer from the dentinal tubule entrances with bactericidal action against microorganisms that are frequently associated with endodontic infections, such as Staphylococcus aureus and Enterococcus faecalis. The high biocompatibility of apple vinegar is mainly attributed to the high concentration of malic acid in its composition. (19)

Estrela et al. $2007^{(10)}$ assessed the smear layer removal capacity of apple vinegar used in isolation and/or associated with EDTA and they observed that the action of apple vinegar in removing the smear layer may be increased when EDTA is associated with the solution. The result of this study also agree with George et al, $2011^{(19)}$, they assessed that the apple vinegar associated or not with EDTA was more effective in removing smear layer from the root canals than $\mathrm{NaOCl}$ associated with EDTA. 
The results of this study also showed that there were no statistically significant differences as regards the different root thirds or sections (coronal, middle, and apical) for the apple vinegar, being in accordance with the studies by Scelza et al. 2004 ${ }^{(18)}$ This is due to the methodology applied, in which the solution used had free passage through the root canal, homogeneously promoting wettability of the root dentin.

The second irregant that shows the best result after the apple vinegar was sodium hypochlorite for the coronal and middle third part of root. Sodium hypochlorite is the most popular root canal irrigant currently used. It is popularity is due to its tissue dissolving property along with being antimicrobial and potent lubricant.

Sodium hypochlorite has a very high $\mathrm{pH}$ which effect on the cytoplasmic integrity with an irreversible enzymatic inhibition, biosynthesis alteration in cellular metabolism, and phospholipids degradation. $\mathrm{NaOCl}$ is a popular irrigant for the excellent lubricant action and broad spectrum of antibacterial activity and its capacity to dissolve organic tissue. It has also been suggested that higher the concentration, the better the antibacterial and tissue dissolution properties. $^{(20)}$ However, along with its many advantages, it has many disadvantages including toxic and bad odor. Many cases of sodium hypochlorite accidents have been reported. Thus, many alternative irrigants have been researched over the years that will overcome sodium hypochlorite various drawbacks. ${ }^{(6)}$ However, the scanning electron microscopic pictures of $\mathrm{NaOCl}$ in the study done by Vallabahaneni K et al, 2017 showed the absence of superficial debris with the presence of smear layer at all root thirds, signifying the inability of $5.25 \% \mathrm{NaOCl}$ incomplete removal the smear layer. ${ }^{(21)}$ These results were similar with Yamada RS et al, 1983 and Baumgartner JC et al, 1984, suggesting that $5.25 \% \mathrm{NaOCl}$ was competent in removing organic and loose superficial debris, leaving exposed inorganic component of smear layer preventing its further removal. (22,23) However Hebatalla E.Kandil et al, (2014) stated that the $\mathrm{NaOCl}$ was an ineffective irrigant to remove the smear layer. ${ }^{(24)}$ These findings are similar to those observed in previous investigations Torabinejad et al. $2003{ }^{(8)}$, Ulusoy and Gorgul, $2011^{(25)}$, Mozayeni et al.2009 (26), that showed these irrigants are not able to remove both organic and inorganic components of the smear layer.

Ginger oil were showed the least effective material for removing smear layer especially at the coronal third of root when it compared to the other parts of the root. This is may be due to low chelating ability of this oil but it still show a good antimicrobial effect in another study. Hence, further research is required and more in vivo studies need to be done to evaluate these root canal irrigants in detail regarding its physical, chemical, biological and antimicrobial properties in order to verify the benefits and consequences to humans.

While normal saline was used in this study as a control group that shows the least effective material in removing smear layer especially at the apical and middle third of root.

Several studies have showmen, that mechanical preparation with manual instrumention and irrigation with saline cannot predictably eliminate the bacteria from the infected root canals ${ }^{(19)}$ Hebatalla E.Kandil et al, (2014) stated that Specimens treated with $\mathrm{NaOCl}$ and saline showed thick smear layer in the three thirds of the root canals. ${ }^{(24)}$

Vemuri S et al, (2016) stated the normal saline was the least effective material in removing of smear layer in all the three parts of the root. ${ }^{(27)}$

The major advantage of these natural alternatives are their easy availability, low cost and most importantly their excellent biocompatible nature with negligible side effects. ${ }^{(28)}$

\section{CONCLUSION}

Although apple vinegar show the best result as irrigating solution, no single irrigant can accomplish all the tasks required by irrigation. Detailed understanding of the mode of action of various solutions is important for optimal irrigation.

\section{REFERENCES}

1. Cohen, S., Burns, R.C.,(2006)Pathways of the Pulp. 9th ed. St. Louis: Mosby.

2. Navarro-Escobar, E., González-Rodríguez, M. P., Ferrer-Luque, C. M. (2010) Cytotoxic effects of two acid solutions and $2.5 \%$ sodium hypochlorite used in endodontic therapy. Med. Oral Patol. Oral Cir. Bucal, 15(1), 90-94. 
3. Agrawal Vineet, S., Rajesh, M., Sonali, K. and Mukesh, P.(2014) A Contemporary Overview of Endodontic Irrigants - A Review. J Dent App, $1(6), 105-115$.

4. Sjogren, U., Figdor, D., Persson, S., Sundqvist, G.(1997) Influence of infection at the time of root filling on the outcome of endodontic treatment of teeth with apical periodontitis. Int Endod J , 30, 297-306.

5. Kirchhoff, A.L., Viapiana, R., Miranda, C.E, Sousa Neto, M.D., Cruz Filho, A.M.(2014) Comparison of the apple vinegar with other chelating solutions on smear layer and calcium ions removal from the root canal. Indian J Dent Res, 25,370-374.

6. Mohanty, S., Ramesh, S., Muralidharan, N. P. (2017) Antimicrobial efficacy of apple cider vinegar against Enterococcus faecalis and Candida albicans: An in vitro study. Journal of Advanced Pharmacy Education \& Research, 7.

7. Nair, P.N., Henry, S., Cano, V., Vera, J.(2005) Microbial status of apical root canal system of human mandibular first molars with primary apical periodontitis after "one-visit" endodontic treatment. Oral Surg Oral Med Oral Pathol Oral Radiol Endod, 99:231-52.

8. Torabinejad, M.,Cho, Y., Khademi, A.A., Bakland, L.K., Shabahang, S.(2003) The effect of various concentrations of sodium hypochlorite on the ability of MTAD to remove the smear layer. $J$ Endod, 29:233-9.

9. Estrela, C. R. A., Estrela, C., Cruz Filho, A. M., Pécora, J. D.(2005) Substância Esp: Opção Na Terapêutica Endodôntica. J. Bras. Endod, 5,273279.

10. Estrela, C., Lopes, H. P., Elias, C. N., Leles, C. R., Pécora, J. D.(2007) Limpeza Da Superfície Do Canal Radicular Pelo Vinagre De Maçã, Hipoclorito De Sódio, Clorexidina E Edta. Rev. Assoc. Paul. Cir. Dent, 61,117-122.

11. Darrag, A.M.(2014)Effectiveness of different final irrigation solutions on smear layer removal in intraradicular dentin. Tanta Dent J, 11,93-9.

12. Gupta, P.K., Mahajan, U.P., Gupta, K., Sheela, N.V. (2015)Comparative evaluation of a new endodontic irrigant - mixture of a tetracycline isomer, an Acid, and a detergent to remove the intracanal smear layer: A scanning electron microscopic study. J Int Oral Health , 7, 1-6.

13. Mittal, A., Dadu, S., Yendrembam, B., Abraham, A., Sharma Singh, N., Garg, P.(2018) Comparison of new irrigating solutions on smear layer removal and calcium ions chelation from the root canal: An in vitro study Endodontology,30,55-61.

14. Torabinejad, M., , Ali, A. K., Babagoli , J., DMD, Yongbum, C., William Ben, J., Bozhilov, K.,
Kim, J.and Shahrokh, S.(2003) New Solution for the Removal of the Smear Layer. 29, NO. 3.

15. Mancini, M., Armellin, E., Casaglia, A., Cerroni, L., Cianconi, L. (2009) Acomparative study of smear layer removal and erosion in apicalintraradicular dentine with three irrigating solutions: A scanningelectron microscopy evaluation. J Endod, 35,900e3.

16. Caligiani, A., Acquotti, D., Palla, G., Bocchi, V. (2007) Identification and quantification of the main organic components of vinegars by high resolution H NMR spectroscopy. Anal Chim Acta, 585:110-9.

17. Spanó, J.C., Silva, R.G., Guedes, D.F., SousaNeto, M.D., Estrela, C., Pécora, J.D.(2009) Atomic absorption spectrometry and scanning electron microscopy evaluation of concentration of calcium ions and smear layer removal with root canal chelators. J Endod, 35:727-30.

18. Scelza, M.F., Pierro, V., Scelza, P., Pereira, M. (2004) Effect of three different time periods of irrigation with EDTA-T, EDTA, and citric acid on smear layer removal. Oral Surg Oral Med Oral Pathol Oral Radiol Endod, 4:499- 503.

19. CandeiroIm, G.M., de Matos, I.B., Eloy da Costa, C.F., Sá Roriz Fonteles, C., do ValeV, M.S.(2011) A comparative scanning electron microscopy evaluation of smear layer removal with apple vinegar and sodium hypochlorite associated with EDTA .J. Appl. Oral Sci, 19 no.6.

20. Mohammadi, Z. (2008)Sodium hypochlorite in endodontics: An update review. Int Endod J, 58:329-41.

21. Vallabhaneni, K., Kakarla, k., Avula, J., Reddy, G., Gowd, M., and Raja Vardhan, K.(2017) Comparative Analyses of Smear Layer Removal Using Four Different Irrigant Solutions in the Primary Root Canals - A Scanning Electron Microscopic. J clinical diagnosis research, 11, 64-67.

22. Yamada, R.S., Armas, A., Goldman, M., Peck, S.L. (1983) A scanning electron microscopic comparison of a high volume final flush with several irrigating solutions. J Endodon, 9:13742.

23. Baumgartner, J.C., Brown, C.M., Mader, C.L., Peters, D.D., Shulman, J.D.(1984) A scanning electron microscopic evaluation of root canal debridement using saline, sodium hypochlorite and citric acid. $J$ Endodon, 10:525-31.

24. Hebatalla, E., Kandil, A., Ahmed, H., Labib, b., Hatem, A. (2014)Effect of different irrigant solutions on microhardness and smear layer removal of root canal dentin. Tanta Dental Journal, 1e11.

25. Ulusoy, O.A., G€orgu, I. G. (2011) Effects of different irrigation solutions on root dentine 
microhardness, smear layer removal and erosion. Aust Endod J, 1e7.

26. Mozayeni, M.A., Javaheri, G.H., Poorroosta, P., Ashari, M.A., Javaheri, H.H.(2009) Effect of $17 \%$ EDTA and MTAD on intracanal smear layer removal: A scanning electron microscopic study.Aust Endod $J, 35: 13 \mathrm{e} 7$.

27. Vemuri, S., Kolanu, S.K., Varri, S., Pabbati, R.K., Penumaka, R., Boll, N.(2016) Effect of different final irrigating solutions on smear layer removal in apical third of root canal: A scanning electron microscope study. $J$ Conserv Dent, 19,87-90.

28. Pujar, M.,Makandar, S.(2011) Herbal Usage In Endodontics- A Review Internationa. Journal of Contemporary Dentistry , 2,34-371

يوخته

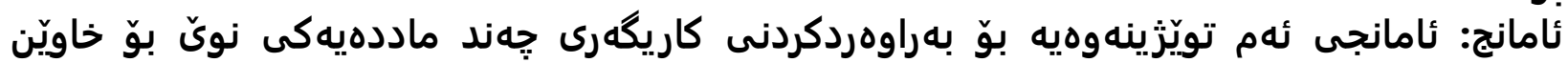
كردنهوهى ناو دهمان

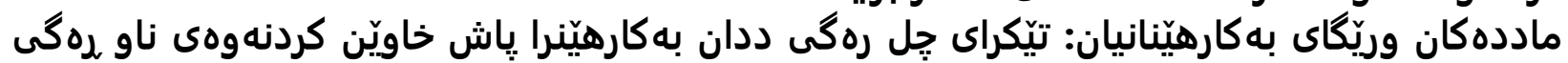

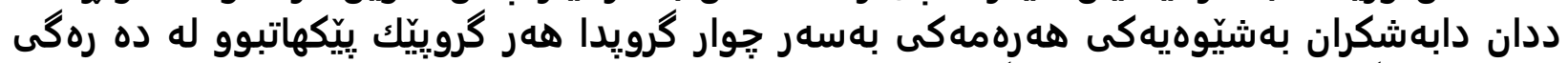

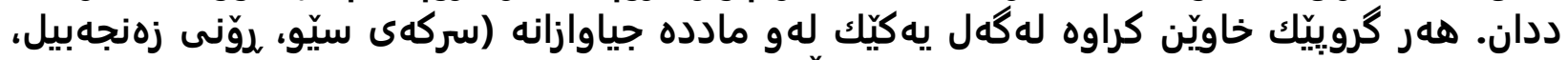

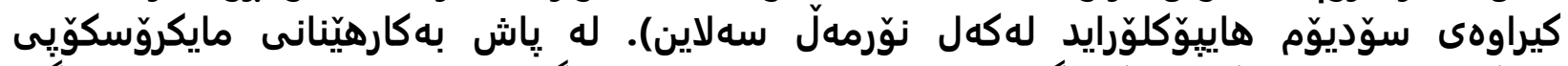

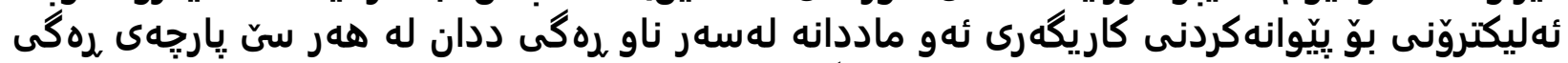

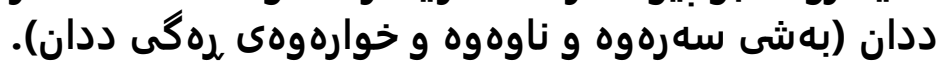

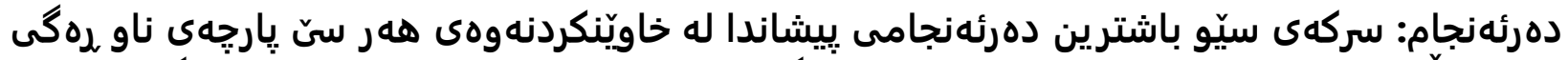

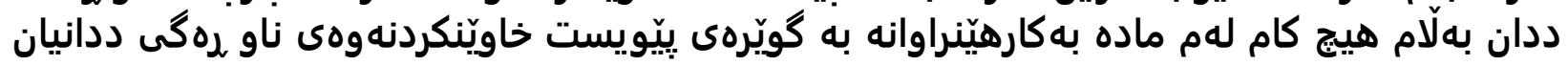
نهردوهوه.

الخلاصة

الهدف: الهدف من هذه الدراسة المختبرية هي لمقارنة كفاءة اربعة محاليل تنظيف في إزالة طبقة اللوثة (اللطخة). المواد وطرق العمل: تم اختيار ما مجموعه اربعين سن من الاسنان ذات الجذور الفور الفردية وتم تنظيف

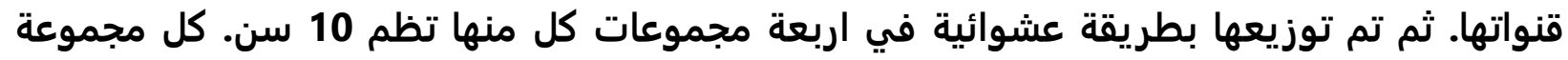

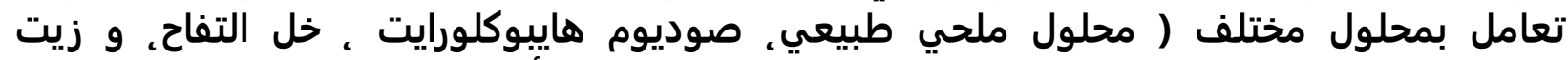

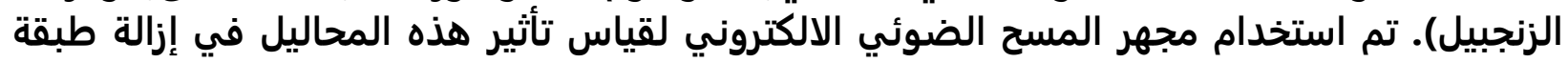

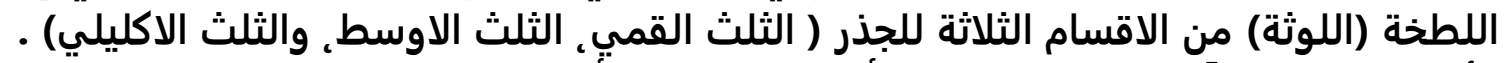

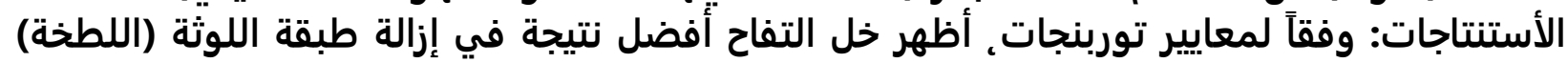

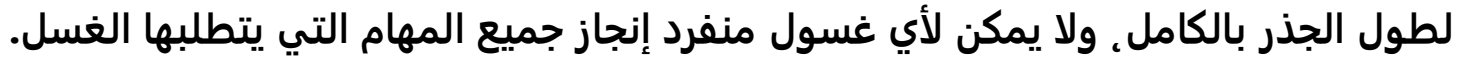

